\title{
貯水池末端における持続的な淡水赤潮に 関する研究 \\ STUDY ON THE MECHANISM SUSTAINING THE LONG TERM FRESHWATER RED TIDE FORMED AT THE RESERVOIR TAIL
}

\author{
天野 邦彦1・田中 康泰 2 ・鈴木 宏幸 3 ・安田 佳哉 4 \\ Kunihiko AMANO, Yasuhiro TANAKA, Hiroyuki SUZUKI and Yoshiya YASUDA \\ 1正会員 工博 建設省土木研究所 環境部環境計画研究室 ( \\ 2正会員 北海道開発局 石狩川開発建設部（テ060-0002 北海道札幌市中央区北 2 条西19丁目） \\ 3建設省土木研究所 環境部環境計画研究室（テ305-0804 茨城県つくば市旭一番地） \\ 4 正会員 建設省土木研究所 環境部環境計画研究室（テ305-0804 茨城県つくば市旭一番地）
}

\begin{abstract}
Freshwater red tide blooms are formed at the reservoir tail in many cases. Dinoflagellates such as Peridinium and Ceratium are usually causative species. These species are unique in being able to swim toward light (phototaxis). This ability makes it possible for them to swim upward during a day. Density currents formed around a plunging point of river water at the reservoir tail seem to help them accumulate around the plunging point. We have surveyed flow structure, water quality changes and diel distribution variation of red tide causing Peridinium bipes at a reservoir tail to investigate the mechanism which leads to a long term continuation of red tide bloom. A continuous surface flow directing upstream was measured at the reservoir tail and $P$. bipes's accumulation at the water surface and upward migration during a day were observed. Most individuals remain at the surface even during night; however, some settled down and were transported downstream by plunged river water which contains available nutrients. This partial settling seems to allow them to take up nutrient from river water without being flushed out throughly.
\end{abstract}

Key Words : Red Tide, Dinoflagellate, Density current, and phototaxis

\section{1. はじめに}

貯水池末端における植物性プランクトンの集積現象は, 淡水赤潮と呼ばれ貯水池によっては毎年のように発生し, 景観障害を引き起こすこともある ${ }^{1)}$. 淡水赤潮の原因と なる植物性プランクトンは, 遊泳能力を持つ渦鞭毛藻類 であることが多いことから，この遊泳能力を持つという 特性と貯水池末端での流れとの関係が貯水池末端での淡 水赤潮集積の原因となっていることが今までの研究で示 されている2）3．

本研究では，淡水赤潮がほぼ句年発生する貯水池末端 において淡水赤潮原因藻類の分布について日周変化を観 測すると共に, 流速分布, 水温, 水質の現地調査を行い, 長期にわたる淡水赤潮の維持が可能な原因について検討 した.

2. 研究目的
先に述べたように，淡水赤潮発生に関しては赤潮原因 藻類の遊泳と貯水池末端での流動との関連の重要性が指 摘されてきている3) 。 しかし，集積に関して遊泳と流動 との関連から説明がついたとしても，比較的栄養塩濃度 の低い貯水池で数ヶ月にわたり安定して淡水赤潮が維持 されるためには，栄養塩の供給に関して疑問が残ってい た. すなわち，貯水池末端表層の非常に限られた範囲に おいて，大量の赤潮原因の植物性プランクトンが，流入 河川から貯水池表層に供給される摂取可能な栄養塩だけ で数ヶ月にわたり維持されるのか，あるいは赤潮原因の 植物性プランクトンの分布が日周変化することで貯水池 末端において河床付近を流下していると考えられる流入 河川水から栄養塩を摂取することで維持されているのか が不明であった。

このため，本研究では，流入端において淡水赤潮が発 生している貯水池で淡水赤潮原因藻類分布の日周変化を 観測し，その挙動をとらえると共に，水温，水質との関 連について検討することを目的としている. 


\section{3. 観測方法}

観測を行った貯水池では，例年 10 月後半頃から流入 端における赤潮の集積が顕著になることから，平成 10 年 10 月 20 日から 1 月 20 日までの 1 ケ月間, 水温 計；流速計，気象観測等の自動計測機器を設置すること で，流動に関する観測を行うと共に，現地採水と機器に よる 24 時間水質測定を上記期間中 4 回行い，赤潮原因 藻類分布の日周変化の観測を行った. 以下に，それぞれ の測定場所，測定方法について述べる.

\section{（1）自動計測機器による測定場所及び方法}

観測対象とした貯水池は，2つの支川が上流端で合流 し流入する形状を持っている（図一1）。測定は，2支 川のうち左支川の流入端より約 2. $5 \mathrm{~km}$ の範囲で河床の 最深部を流下方向に継断的な調查が可能となるように測 定点を設定した（図一 1 ）。本貯水池は，測点No. 1 と 2 の間に夏期水位低下時の取水堰（天端標高 $317 \mathrm{~m}$ ） が 設けられているが，観測期間中は水没していた.

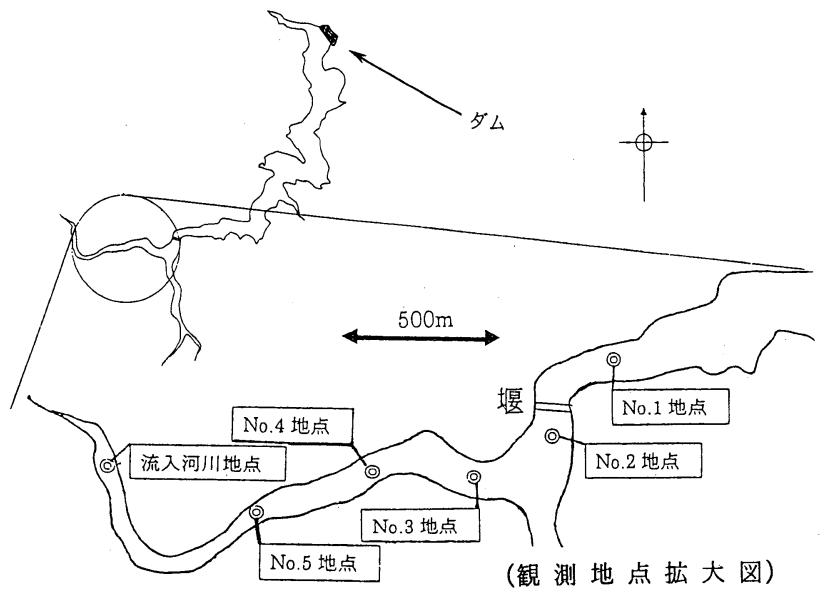

図-1 観測対象貯水池平面図及ひ観測地点拡大図.

自動計測機器の配置については，以下の通りに行った。

\section{a) 流速計の配置及び測定方法}

No. $1 〜 4 の 4$ 地点の河床上にAD C P を設置すると 共にNo. 1〜 5 の 5 地点の河床から 0. $5 \mathrm{~m}$ 上に電磁流 速計を設置し，バースティングモードでそれぞれ 30 分 間隔で流速測定を行った.

\section{b）水温計の配置及び測定方法}

流入河川地点の河床 1 点，またNo. 1〜 5地点では水 深方向に水温計をチェーン状に配置した. 観測期間中の 水位変化が予測されたこと，また先に述べた水没した堰 に低水温塊が貯留されていることから，これが流動に与 える影響について調査するためにNo. 1 地点（堰下流） では，湖底上 $1 \mathrm{~m}$ から $12 \mathrm{~m}$ まで1mおきに 12 点立ち上げる と共に水面から $0.5,1 ， 2 ， 6 ， 10 \mathrm{~m}$ 水深の 5 点の合計 1 7 点, No. 2 及び 3 地点では, 湖底上 $1 \mathrm{~m}$ 及び水面から 0.5 ,
$2,4,6,8,10,12,14,16 \mathrm{~m}$ 水深の 9 点の合計 10 点, No. 4 地点では，湖底上 $1 \mathrm{~m}$ 及び水面から $0.5,2,4,6,8$, $10,12 \mathrm{~m}$ 水深の 7 点の合計 8 点, No. 5 地点では湖底上 $1 \mathrm{~m}$ 及び水面から $1 \mathrm{~m}$ 水深の合計 2 点に水温計を設置した（図 -2）. 測定間隔は 10 分とした.

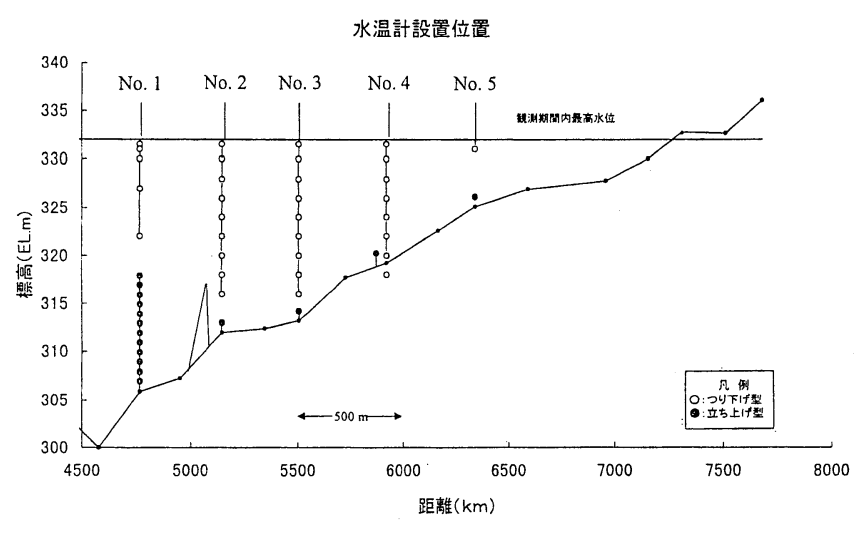

図一2 水温計設置位置図.

\section{c) 気象計の配置及び測定方法}

気象観測については, 日射量, 気温, 風向風速, 湿度 についてNo. 2 地点の左岸で観測を行った. 日射量につ いては 30 分毎に積算值を, 気温, 風向風速, 湿度につ いては 10 分間隔で測定を行った.

\section{（2） 24 時間水質測定場所及び方法}

24 時間水質測定については, 調査船を用いてNo. 1 〜 5 地点および可能な限り No. 5 地点より上流側に移動 し機器測定により水温, $\mathrm{pH}$ ，クロロフィルー $\mathrm{a}$ ，水中照 度の 4 項目について水深 $0.1 ， 0.5 ， 1.0 \mathrm{~m}$ から $1 \mathrm{~m}$ 毎に水底 まで維断的にほぼ 4 時間おきに観測した.

また，栄養塩に関する測定として，リン ( $\mathrm{T}-\mathrm{P}, \mathrm{PO}_{4}-\mathrm{P}$, 0-P），窒素（ $\mathrm{T}-\mathrm{N}, \mathrm{NO}_{3}-\mathrm{N}, \mathrm{NH}_{4}-\mathrm{N}, 0-\mathrm{N} ）$ を流入地点及び 原則としてNo. $1 \sim 5$ 地点の表層, 中層, 底層でバン ドーン型採水器を使用して採水後, 速やかに実験室に持 ち運び分析を行った. 測定は 4 回行った 24 時間調査の うち 3 回については 1 日 1 回，残りの 1 回については 1 日 2 回（昼間及び夜間）の合計 5 回行った.

さらに，プランクトンに関する測定として，植物性プ ランクトンの定量分析及びクロロフィルー $\mathrm{a}$ を栄養塩と 同様の場所で採水，分析することで測定した. ただし， 植物性プランクトンの定量分析とクロロフィルー a につ いては，機器測定によるクロロフィルー $\mathrm{a}$ との相関をと る目的から, 測定は 4 回行った 24 時間調查のうち 3 回 については 1 日 1 回, 残りの 1 回については 1 日 7 回 （ほぼ4時間毎）の合計 10 回行った.

\section{4. 結果}

\section{（1）水温分布}

No. 3 地点における水温変化を示す等温線図（図一 
3）から, 観測期間を通して, 天端標高 $317 \mathrm{~m}$ の水没 堰上流に貯留されている底部の低水温水塊の影響のため, 標高 $320 \mathrm{~m}$ 付近に水温躍層が存在していたことが分か る. この水温鉛直分布は放流の影響を受けたダムサイト 地点とは全く異なっており，この堰の影響と考えられる.

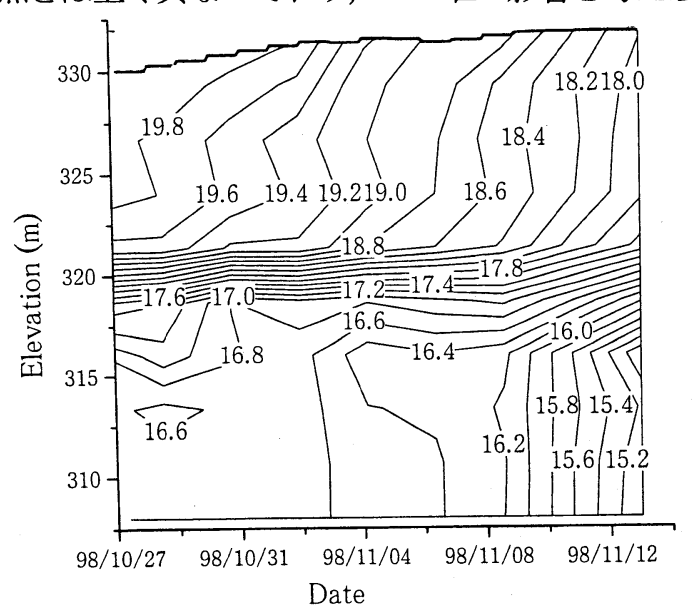

図-3 No. 3 地点における等水温線図.

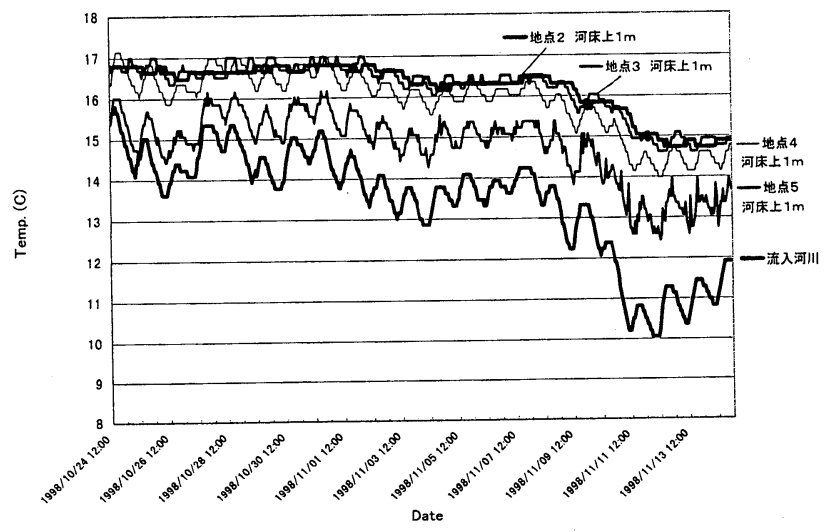

図-4 流入水温及ひNo. 2〜 5地点での河床上 $1 \mathrm{~m}$ 水温の変化. 流入河川水温は, 期間中約 $16^{\circ} \mathrm{C}$ から気温の低下に伴 い $10^{\circ} \mathrm{C}$ 程度にまで低下した（図一4）。また, 流入河 川水温は規則的に $1^{\circ} \mathrm{C}$ 程度の日周変動を示した. 貯水池 に流入した河川水は，貯水池表層水温より $5^{\circ} \mathrm{C}$ 以上低い ため，底層を流下することが考えられる．図一4は，流 入河川水温の変化と共に水没した堰上流の 4 測点での河 床上 $1 \mathrm{~m}$ での水温変化を同時に示しているが，No. 4 及 び5地点では, 河床標高が堰天端より高いため底層を流 下寸る河川水の影響を直接受け, 両地点河床上 $1 \mathrm{~m}$ での 水温変化は, 流入河川とほぼ同様の変化傾向を示すこと が分かる. しかし, 流入河川水は, 標高 $320 \mathrm{~m}$ より高 い位置に存在する高温の表層水と混合するため, No. 5, No. 4 地点へと流下寸るに従い, 水温が $1{ }^{\circ} \mathrm{C}$ 程度ずつ上 昇していた。これに対してNo. 2 及び 3 地点は, 河床が 堰より低いため, 河床上 $1 \mathrm{~m}$ 水深での水温変化は流入河 川水温変化の様な日周変化は示さず, 水温変化は非常に 緩慢であった. しかし，水温変化の傾向としては流入河 川水温の変化傾向に従い，特に流入河川水温が急激に低
下した 11 月 12 日以降 $1^{\circ} \mathrm{C}$ 以上の低下を示した（図一 4).

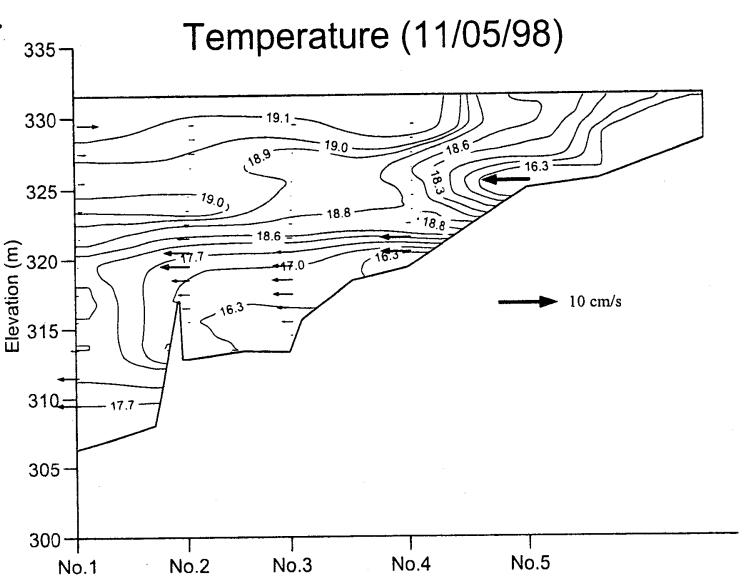

図-5 11 月 5 日午後 3 時の縦断面等水温線及び平均流下方向 流速分布図.

第 2 回目の 24 時間調査が行われた 11 月 5 日午後 3 時の水温の縦断面等温線を図一 5 に示す. コンピュータ による作図のため, No. 4 と 5 地点の間での底層水温分 布に若干難があるが，流入河川水が底層を流下すること と，堰により低温水塊がNo. 2 地点からNo. 4 地点直下流 までに存在することが分かる。

\section{（2）流速分布}

図一5には，ADC P及び電磁流速計によって得られ た 1 1月 5 日の日平均流下方向流速分布を同時に示して いる. 水温の繸断面等温線と矛盾無く, 流入端からNo. 4 地点付近まで流入河川水が河床上の底層を流下し，そ の下流で，堰による底層低温水塊の上，標高 $320 \mathrm{~m}$ 付 近を中心に貫入している様子が良く示されている．堰を 越えた流入水は，下流の貯水池水に比べて密度が高いた め，再び河床付近を流下することが図から示されている.

No. 2 地点でのAD C P及び電磁流速計による流速の 連続計測結果を図一6に示す．本地点では，ほぼ北方向 が流下方向に当たっている．観測期間中は，大きな出水 もなく，このため，流入河川水の流下と考えられる標高 $320 \mathrm{~m}$ 付近の水深を中心に最大值 $(7 \mathrm{~cm} / \mathrm{s}$ 程度) を示 す流下方向流速は，期間中大きな変化を示すことなくほ ぼ一定の值を示していた.

これに対して，表層 3〜 4 $\mathrm{m}$ 付近では，上流側に向か う流れが観測されている．表層付近の流れは風の影響を 受けることから変動が大きく，特に昼間に上流側へと流 れる流速が大きくなる傾向が見られる.

\section{（3）栄養塩濃度}

流入河川水質は，期間中 5 回行った測定結果の中では, 大きな変動は見られなかった．窒素については，T-Nで $0.23 \sim 0.35 \mathrm{mg} / 1$ の範囲で変化したが， $\mathrm{NO}_{3}-\mathrm{N} て ゙ 0.19 \sim$ $0.27 \mathrm{mg} / 1, \mathrm{NH}_{4}-\mathrm{N}$ は検出されず，0-Nで0.04〜0.14mg/1の 值を示した．全ての測定において，窒素の項目中で $\mathrm{N}_{3}-$ 


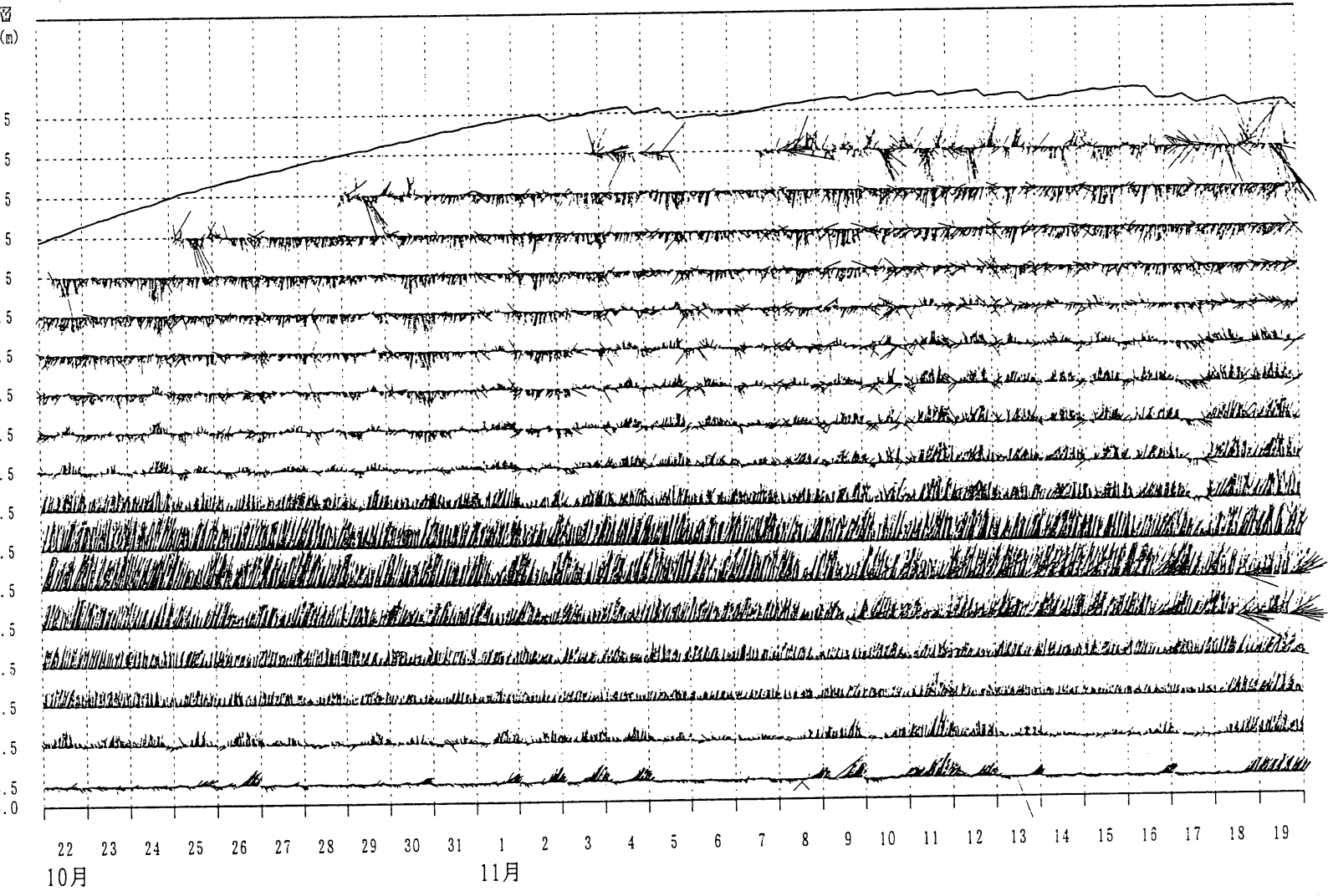

図-6 No. 2 地点でのADC P 及び電磁流速計による流速の連続計測結果.

Nが最も大きな割合を示していた。 リンについては，T$\mathrm{P}$ で 0.011 ～ $0.013 \mathrm{mg} / 1$ とほとんど変化せず, $\mathrm{P}_{4}-\mathrm{P}$ で $0.006 \sim 0.009 \mathrm{mg} / 1 ， 0-\mathrm{P}$ は検出されないか0.006〜 $0.01 \mathrm{mg} / 1$ 範囲で分布した. 1 回の測定を除いてリン の項目中 $\mathrm{PO}_{4}-\mathrm{P}$ が50\%以上の割合を占めていた．流入河川 水中のクロロフィルー $\mathrm{a}$ 濃度は最大值で $5.3 \mu \mathrm{g} / 1$ と貯 水池水に比べて低い值を示した。

貯水池流入末端では，栄養塩濃度の变化は後述する ように赤潮藻類の分布に大きく影響を受けていた。例 えば，测定した検体中クロロフィルー $\mathrm{a}$ 濃度の最大値 は，赤潮が集積した箇所から採水したもので，438 $\mu$ g/1と非常に高い值を示したが，この検体のT-N，0-N濃 度はそれぞれ3.79，3.60mg/1，T-P，0-P濃度はそれぞ れ0.271，0.269mg/ 1 と流入河川水濃度に比べてT-Nで 1 0 倍以上，T-Pでは 20 倍以上の高濃度を示していた。

リンに関しては，藻類による攝取と考えられるが, 貯水池内での測定からはP0 $-\mathrm{P}$ は全く検出されず，また 上の例からも示されるように，T-P濃度のほとんどは0$\mathrm{P} て ゙$ 占められていた，貯水池内での窒素に関しては，リ ン同様，0-N濃度は赤潮藻類の分布に大きく影響を受け て変化する分布を示したが，窒素については観測期間 中, 藻類増殖の制限因子とはなっていなかったようで, 藻類が利用可能な溶存性無機態窒素である $\mathrm{NO}_{3}-\mathrm{N} か ゙$ 赤潮 藻類が大量に集積していた $2 ， 3$ の検体を除いて 0.1 $0.2 \mathrm{mg} / 1$ 残存していた.
（4）植物性プランクトン分布

観測方法の項で述べたように，植物性プランクトン については，採水した検体について，検鏡による植物 性プランクトンの定量分析及びクロロフィルー $\mathrm{a}$ 濃度 分析を行うと共に，現地で機器による詳細なクロロ フィルー $\mathrm{a}$ 測定を行っている. 植物性プランクトンの 定量分析結果からは，期間中測定された植物性プラン クトンの優種は赤潮原因藻類のPeridinium bipesであっ たことが示された．表一 1 は，P. bipesに続いて多く検 出された珪藻類のAsterionella formosa，P. bipesの細胞濃 度, 窒素, リン, クロロフィルー $\mathrm{a}$ 濃度との相関を一 覧表にして表したものである.P. bipesが圧倒的な優占 種であったため，O-N，O-P，クロロフィルー a との相関 が非常に高いことが分かる.

表一1 植物性プランクトン，栄養塩濃度等相関一覧.

\begin{tabular}{|c|c|c|c|c|c|c|c|c|}
\hline 単相関 & $\begin{array}{l}\text { Asterionella } \\
\text { formosa }\end{array}$ & $\begin{array}{l}\text { Peridinitw } \\
\text { bipes }\end{array}$ & $T-.1$ & $\begin{array}{c}\text { Org- } \\
1\end{array}$ & $T-P$ & $\begin{array}{l}\text { Org- } \\
\quad P\end{array}$ & 舁 & $\begin{array}{c}\mathrm{Ch} \\
\mathrm{a}\end{array}$ \\
\hline $\begin{array}{l}\text { Asterionella } \\
\text { formosa }\end{array}$ & 1.0000 & & & & & & & \\
\hline Peridiniu bipes & 0.1124 & 1.0000 & & & & & & \\
\hline$T-N$ & 0.0700 & 0.7867 & 1.0000 & & & & & \\
\hline$O r g-N$ & 0.0834 & 0.7930 & 0.9993 & 1.0000 & & & & \\
\hline$T-P$ & 0.0012 & 0.8915 & 0.8859 & 0.8909 & 1.0000 & & & \\
\hline Org-P & 0.0104 & 0.8910 & 0.8868 & 0.8924 & 0.9996 & 1.0000 & & \\
\hline 湿度 & -0.0077 & 0.8288 & 0.7678 & 0.7706 & 0.9319 & 0.9312 & 1.0000 & \\
\hline$C h l-a$ & 0.1391 & 0.8672 & 0.8893 & 0.8962 & 0.9605 & 0.9663 & 0.8883 & 1.0000 \\
\hline
\end{tabular}




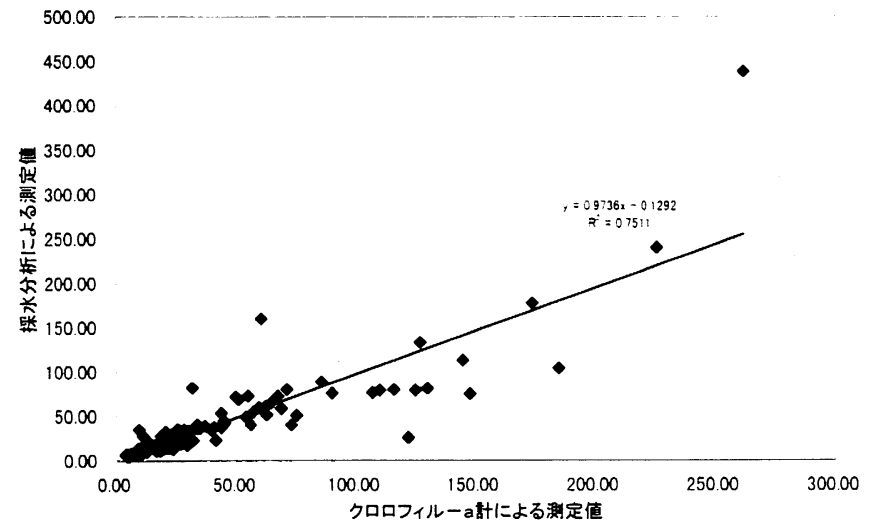

図-7 機器観測と水質分析によるクロロフィルー $\mathrm{a}$ 分析比較.
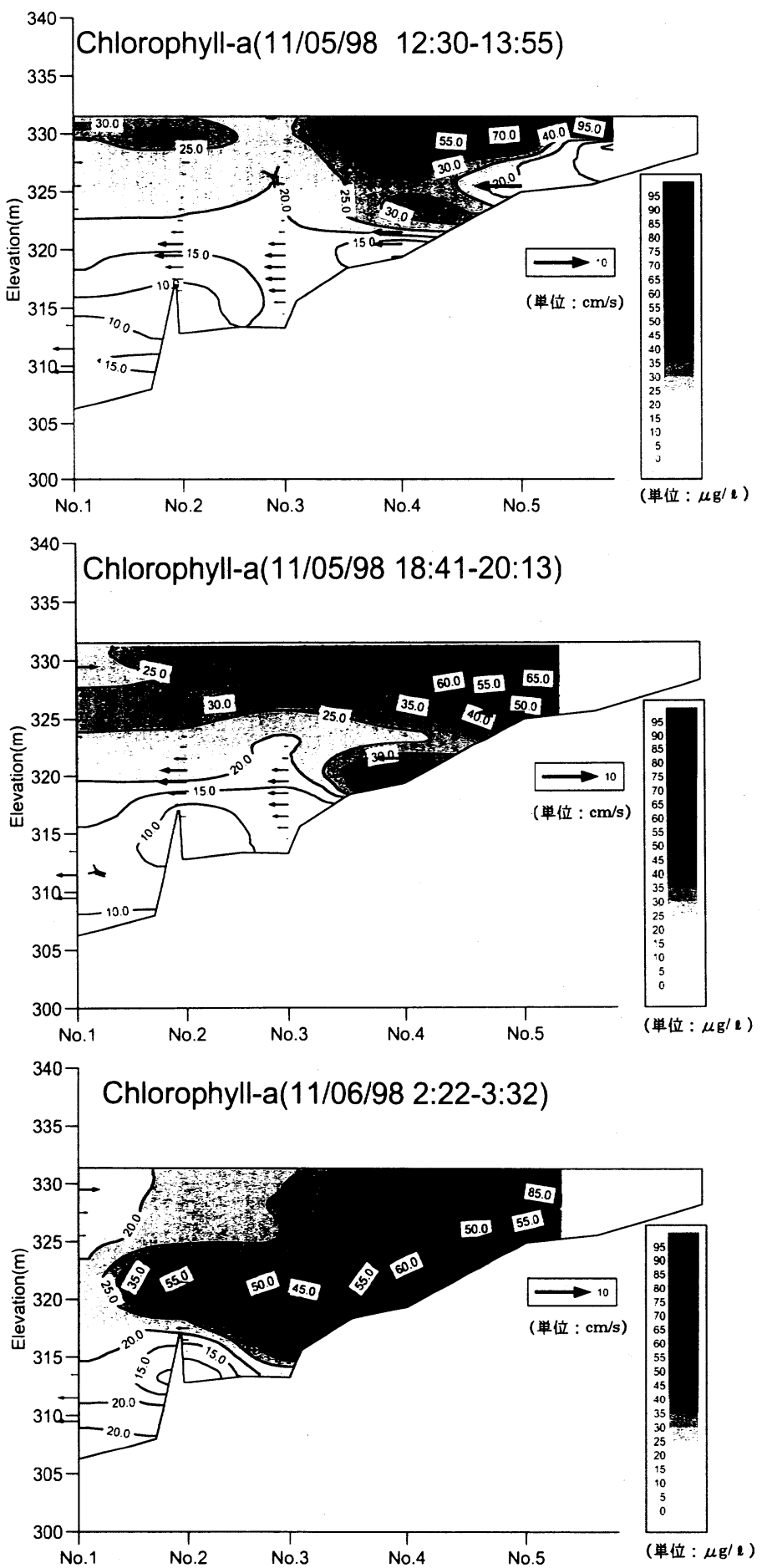

機器観測と水質分析から得られたクロロフィルー $\mathrm{a}$ 濃度の間にも良好な相関が得られた（図一7）。

ここで得られた回帰式を用いて現地での機器測定に よる詳細なクロロフィルー $\mathrm{a}$ 計測結果を変換してクロ ロフィルー $\mathrm{a}$ 濃度の日周変化を示したのが図一 8 であ る.ここでは，第 2 回目の 24 時間調查の結果を示す. 表一 1 に見られるようにクロロフィルー a とP. bipes細 胞濃度との相関が約 0.87 と非常に高いことから，この結 果は赤潮原因藻類であるP. bipes細胞濃度の分布と見る ことができる
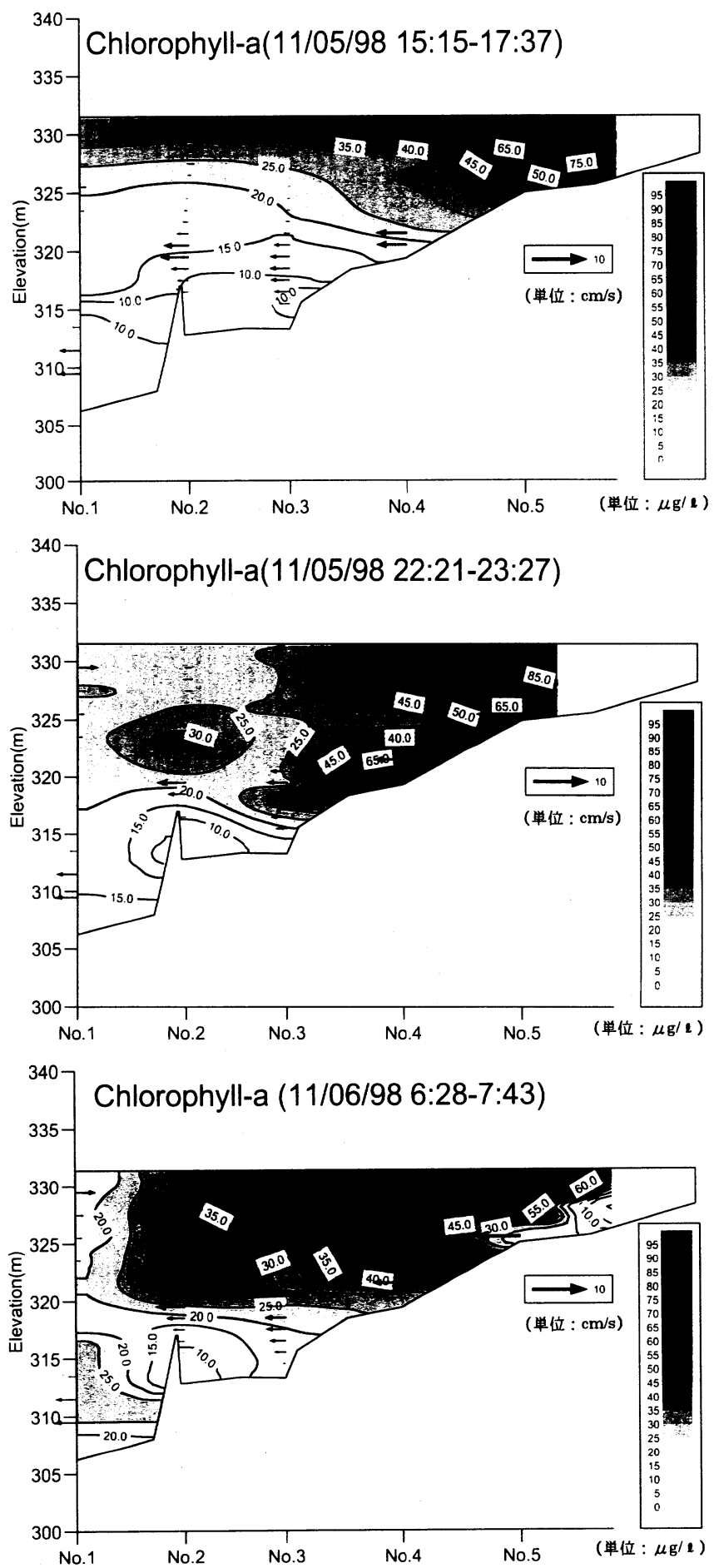

図-8 第 2 回 24 時間連続観測時のクロロフィルー $\mathrm{a}$ 濃度維断分布の変化. 
午後12時30分から 13 時55分にかけて計測された分 布図からは，流入端付近表層へのP. bipesの集積に よるピークが見てとれる。このとき，底層付近での クロロフィルー a は低い值を示していた。次の15時 15分からの観測では, 流入端付近での底層クロロ フィルー $\mathrm{a}$ 濃度の上昇が見られ, 流入端表層に集積 していた $P$. bipesの一部が沈降したと考えられる. 18時41分からの観測ではNo. 4付近の底層に沈降した P. bipesが流入河川水により運ばれたと考えられる ピークが見られた.ここで，図中の矢印は A D C P 及び電磁流速計により得られた流下方向流速の日平 均値の分布を示している. 流入河川水により下流と運ばれたと見られるP. bipesの底層での最大值は No. 4地点底層で22時21分からの観測に見ることが出 来る. さらに, 次の日の午前 2 時 22 分からの観測で は，堰上流底層に滞留している冷水塊の上を流下寸 る流入河川水の流れによりP. bipesが運搬されてい ることによると考えられるNo.4地点からNo. 2地点下 流までに至る中層でのクロロフィルー $\mathrm{a}$ 濃度のピー クが示された。この後に行われた午前6時28分から の観測では, この時点でP. bipesの上昇運動がすで に始まっていたと考えられ, 流入端付近の底層での クロロフィルー $\mathrm{a}$ 濃度は再び低下し（5 $\mu \mathrm{g} / 1$ 以下）， 午前 2 時 22 分からの観測で認められた中層でのクロ ロフィルー $\mathrm{a}$ 濃度のピークは認められなかった. 代 わりに, No. 4地点からNo. 2 地点下流での標高 $320 \mathrm{~m}$ 以浅でのクロロフィルー $\mathrm{a}$ 濃度が全般的に上昇して おり，午前 2 時 22 分からの観測で認められた流入河 川水により下流へと運搬された . bipesが上昇運動 をすることでこのような分布になったと考えられる.

\section{5. 考察}

安定した水温成層が貯水池表層付近に形成される ことで, 本貯水池末端では, 観測期間中を通して流 入河川水の中底層流下，これを補償していると考え られる表層での上流へ向かう流れが維持され，この 流れが走光性を持ち昼間上昇運動をしていると考え られる ${ }^{4)}$ 赤潮原因藻類のP. bipesにとって, 長期間 にわたる貯水池末端表層での集積及び栄養塩摂取に 有利な条件を提供していると考えられる.

すなわち，昼間貯水池流入端表層に集積した $P$. bipesは, 表層において昼間平均 $1 \sim 3 \mathrm{~cm} / \mathrm{s}$ 程度の緩や かな上流へ向かう流れにより河川水の潜り込み点付 近まで運搬されると考えられる ${ }^{5)}$ 。昼間は潜り込 む河川水に連行されても, 上昇運動を行うため, 再 び表層付近に戻ると考えられる．このことは，貯水 池末端表層での集積は一部のP. bipesの沈降が認め られる夕刻前に最大となることから示唆される.

夜間は，P. bipesの一部が沈降していることが観 測結果から示されている. 夜間の運動能の低下に伴 う沈降が表層での集積の消失を説明しうるとされて (る ${ }^{3)}$ こと, 今回の観測結果からも夜間に表層に 残留するものの方が多いこと, また海洋で赤潮を引
き起こすラフィド藻のChattonella antiquaの様に夜間 下降運動をする種であれば，夜間の分布のピークは

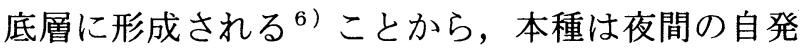
的下降運動は行わない可能性があると考えられる.

観測された流入河川の流下速度は標高 $320 \mathrm{~m}$ で $5 \mathrm{~cm} / \mathrm{s}$ 程度であり，この速度でP. bipesも流下した とすれば，沈降がNo. 5 地点上流で認められた午後 6 時からNo.2地点中層にピークが到達した午前 3 時ま での 9 時間で約 $1.6 \mathrm{~km}$ 流下寸ることが可能で，これ はクロロフィルー $\mathrm{a}$ 分布の観測值から認められる流 下距離と一致している.

しかし，先述したように，表層での上流に向かう 流速はこの半分以下であり, このため, もし大多数 のP. bipesが沈降していたとすると, 大半が昼間に 流入端まで戻りきることなく下流に流されてしまう と考えられる. また逆に，P. bipesが全く沈降しな ければ，貯水池表層の利用可能なリンは枯渴してい るため，赤潮はやがて消滅すると考えられる.

P. bipesの一部が何らかの理由で夜間に沈降すれ ば, 貯水池表層とは異なり，利用可能なリンが存在 する流入河川水に到達することで，これらの個体は リンの摂取が可能であると考えられる.この一部の 個体のみが夜間沈降，流下しているということが， 貯水池末端でのP. bipes赤潮の長期間にわたる維持 を可能にしていると考えられる。

\section{6. 結論}

貯水池末端に形成される淡水赤潮原因藻類 $P$. bipesは, 貯水池末端での流れにより集積が可能と なると共に, その一部のみが夜間に沈降することで 長期間にわたり栄養塩摂取と個体数の維持が可能に なっていると考えられる.

\section{参考文献}

1) 山中芳夫 : わが国各地における淡水赤潮の発生状況, 淡水赤潮，恒星社厚生閣，PP.165-170, 1987.

2) 畑幸彦 : 永瀬夕゙ム湖におけるPeridiniumによる赤潮現象, 国立公害研究所研究資料, 第24号, B-24-'83, pp. 1528, 1983.

3) 渡辺仁治, 清水晃, 石井玉恵, 坪田智子 : Peridinium bipes f.occulatum(Lemm.)Lef.による淡水赤潮の発生機構 に対する考察, 国立公害研究所研究資料, 第 24 号, B24-'83, pp. 29-48, 1983.

4) 山田正人, 宗宮功, 安永望, 小野芳朗: 渦鞭毛藻 Peridiniumの走光性による遊泳速度に関する研究, Jpn. J. Limnol., Vol.56, pp.125-135, 1995.

5) 天野邦彦, 田中康泰, 寺川陽 : 貯水池末端における流 れと淡水赤潮の関連に関する研究, 日本流体力学会年 回'99講演論文集, pp. 437-438， 1999.

6) Watanabe, M, Kohata, K, Kimura, T., Takamatsu, T., Yamaguchi, S. and Ioriya, T.:Generation of a Chattonella antiqua bloom by imposing a shallow nutricline in a mesocosm, Limnol. Oceanogr., Vol.40, pp.1447-1460, 1995. 